\title{
When Boundaries Need to be Crossed. A Brief History of Research Projects
}

Received: October 24, 2020 • Accepted: November 1, 2020

Csaba Mészáros

Institute of Ethnology, Research Centre for the Humanities, Budapest

The present selection of articles in Acta Ethnographica Hungarica marks a milestone in the research work that began nearly a decade ago and that will continue in the coming years. Anthropological research focusing on the Hungarian-Slovenian border has been funded through a series of successful grant applications. Two research projects were launched in 2012. The first, An examination of triple borders in the southwestern, southeastern, and northeastern regions of Hungary, implemented by the Institute of Ethnology of the Hungarian Academy of Sciences, was funded by the Hungarian State Research Fund. The project focused on life strategies in borderland regions, and cross-border communication. Two monographs were published in the framework of this project, one on the theoretical problems that arise in the context of borderland studies and the other presenting case studies from the Hungarian-Slovenian border area (TURAI 2015; TURAI - MÉSzÁROS 2015). The second research project was realized in the framework of an inter-academic bilateral project involving researchers from Slovenia (based predominantly at the Institute of Slovenian Ethnology of the Research Centre of the Slovenian Academy of Sciences and Arts) and the Institute of Ethnology of the Hungarian Academy of Sciences. This project, Mobility, diversity, and ethnicity in the Slovenian-Hungarian border area, brought together researchers with an interest in cross-border ethnic relations and the experiences of Slovenians living in Hungary and Hungarians living in Slovenia.

After the completion of these two projects in 2015 and 2016, the researchers were keen to continue their joint activities. While carrying out fieldwork in the area, it had become apparent that, for many of the villagers, one of the biggest problems were somehow connected with the activities of the Örség National Park and with NGOs working in the field of environmental protection. The idea therefore emerged that the composition of the research team should be modified somewhat to include experts from the natural sciences. The new research team thus not only crossed state borders (by including both Slovenian and Hungarian researchers), but also transcended disciplinary borders by incorporating an ethno-zoologist and an ethnobotanist.

The new project, Protected areas in the Hungarian-Slovenian border area: Challenges in cooperation and sustainable development, sponsored by both the 
Hungarian and Slovenian state research agencies, began in 2017 and was due to end in 2020. In fact, owing to the COVID pandemic, research activities and funding were extended in Hungary, thus the project will be finalized only in 2021. Besides other outputs, one of the milestones of this project was the publication of a collection of 10 articles by participating researchers in the Slovenian journal Traditiones in 2019, in the issue Protected Areas along the Slovenian-Hungarian Border.

The current issue of Acta Ethnographica Hungarica, which includes 11 research articles by the joint research team, does not mark the final stage in the research. In September 2020, a new research group was formed, in which experts from the field of natural sciences were strongly represented. This new group draws on the interplay between the social and natural sciences to study land use and traditional ecological knowledge in peripheral village communities in the Carpathian Basin. One of the field sites targeted by this research group is the Hungarian-Slovenian border area.

Anthropological (or rather ethnographic) research work in fact has a far longer history in this area, thus the authors are partly aiming to enrich an existing research tradition through their contributions, while at the same time providing new insights and identifying innovative research topics in the area.

\section{CULTURE AND STATE BORDERS}

The first monograph on the region was written in 1818 (NEMESNÉPI ZaKÁL 2002). The rich cultural heritage of the Örség region has already been described on many occasions by historians and art historians (KogUTOWITZ 1930; KERNY 2005). This cultural wealth can be explained by the special legal status (VöRös 1970; МоHos 2008) that makes the region unique (NAGY 1999). Local architecture and pottery making are prominent features of Hungarian folk culture (BíRó 1975; DöмÖтÖR 1960). Due to the unique legal position of Örség (STAHL 1974) and its settlement type (Prinz 1922), various ethnographic studies have focused on local architecture (GRÁFIK 1995) and the relationship between traditional economic activities and local agriculture (GYÖNGYÖSSYI 2003). In the mid$20^{\text {th }}$ century, the peripheral position of Örség became increasingly apparent (PÁveL 1936; VAKARCS 1949).

The ethnographic literature clearly illustrates how the Hungarian village communities in the Örség region and the Slovenian communities in the Slovenian Raba region lived within a densely woven fabric of family and social ties - ties that were mostly broken after 1920. The borders became increasingly visible as the entire infrastructure of border guarding became more complex and extensive in the $20^{\text {th }}$ century. This tangible, objectified border divided family groups and friendships: even siblings and cousins were unable to meet for decades. From the 1970s, in the era of détente, Hungary and Yugoslavia began gradually to dismantle the hard border, thus connections between neighboring villages were revitalized. After the $1990 \mathrm{~s}$, crossing the border was no longer problematic, thus borderland communication intensified. However, within the space of a decade cross-border activities had dwindled, and, following the euphoria of unhindered contact, these activities declined to the level of a mutual lack of interest. When the visible borders were dismantled, invisible borders emerged between communities that had once been closely related. 
After 1920, when the imposed border cut through a previously integrated region, traditional center-periphery relations disintegrated and the Örség region lost its nearest municipal center, Lendava. Owing to the dispersed settlement pattern characteristic of the region, it proved impossible for Öriszentpéter to evolve into the overall center of the region, thus Örség not only acquired a peripheral position within the new borders of Hungary, but also lacked a regional urban center. As a consequence of this peripheral and marginalized position, Örség became one of the least developed areas (in terms of infrastructure) in Transdanubia. Strict border controls in the 1950s left border areas in Hungary even more isolated.

This extremely peripheral position was further emphasized on the Hungarian side of the border by the failure of Socialist modernization efforts in the region. The unfavorable ecological conditions made the management of the newly created collectives and state farms difficult, while industrial developments were restricted to urban centers. The area thus preserved its mosaic landscape, dominated by orchards, meadows, pastures, forests, and arable lands. This unique landscape, on both sides of the border, prompted the emergence of local and state institutions for the protection of the environment. Almost the entire border area is now included within the Örség National Park and the Goričko Natural Park. The interface between culture and nature is thus a key issue for this region.

The Örség cultural landscape is now a protected area in both Hungary and Slovenia. What appears to visitors as an unspoiled, virgin landscape is the outcome of centuries of cultivation by local farmers. The parents and grandparents of today's villagers not only preserved this landscape but actively participated in its formation and management. Knowledge of the soil, vegetation, and cultivation methods was passed from generation to generation. However, in terms of land management there are big differences between Hungary and Slovenia: while collectivization and new methods of agricultural production radically changed ecotopes on the Hungarian side of the border during the Socialist era, these landscape features remained relatively untouched in the former Yugoslavia, where smallholders were able to continue farming. On the Hungarian side, melioration and intensive crop production changed the landscape, while in Yugoslavia a more laborintensive style of farming became widespread. Yet despite these differences, the region as a whole is now approached by ecologists as one unit.

\section{NATURE AND STATE BORDERS}

Borders divide communities, while border crossings are regulated by means of decisions made in the centers. Residents of border areas have no say over such matters and are unable to influence decisions as to who is kept in and who is kept out. The maintenance and monitoring of borders (whether restricted or encouraged) are tasks that fall within the purview of the government, which means the addition of new infrastructure and personnel to the peripheral communities. Individuals and communities living close to a nation's borders must either accommodate such decisions, or circumvent them. The same applies to environmental policy. Decisions as to what should be preserved in the regions, and how, are made in the centers. The creation of national parks in border areas likewise entails the appearance of new infrastructure and personnel. In this respect, state borders and national parks have a similar impact on peripheral communities. 
As a controlled dividing line, a state border, like the border of a national park, can divide a community; it can allow people, things, and information to filter through, and it can precipitate relationships and interactions among the residents on either side. In the respective areas, the border acquires a substantial symbolic weight, against which individuals must continually position themselves. The border is a hub where the local, national, and ecological spheres collide and, as such, it is a determining factor in the formation of identities, everyday activities, and the life strategies of families and individuals.

National borders are physical dividing lines that belong to the state monopoly; they are controlled areas in which the flow of people, goods, information, and capital is strictly regulated according to national interests. The borders of national parks also belong to the state monopoly, but they are there to restrict and regulate people's behavior with respect to the natural world.

The role of borders in delineating space affects the day-to-day lives of local communities. State borders and national park borders present both obstacles and opportunities, their dual nature allowing them simultaneously to separate and unite. They are a projection of macro-level geopolitical concepts to which local communities must acclimatize, responding on the basis of their own identities ("us" versus "them") and cognitive spatial constructs.

\section{CULTURE AND NATURE}

In the social sciences, the opposition between nature (physical space and the non-built environment) and culture has been an essential element of the modernist episteme (DESCOLA 2013:78-83). Works in the field of ethnography and anthropology influenced by this approach have presumed that social and cultural processes that take place against the backdrop of the natural environment - which is static or subject to imperceptible changes - obey entirely different rules (DEGLER 1989). Although the two spheres may come into contact, they are essentially disparate and dissociable.

By treating nature and culture as different entities, researchers have tended to adopt an anachronistic approach to the two spheres, in which the natural environment is regarded as constant and stable (and therefore negligible) when viewed in the context of the study of a single culture. The Hungarian-Slovenian border region provides an instructive example of parallel socio-natural developments on both sides of the border.

The safeguarding of the natural environment nowadays ensures an important economic asset for the entire region. Eco-friendly or green tourism is one of the main directions in terms of local development policies, not only helping local NGOs, but potentially also contributing to the formation of a strong regional identity (FEHÉRVÖLGYI 2010:136-138). Recent developments such as the Apple Festival and the Apple Press House, as well as the NGO-run community orchard and the Raba Valley fruit trail illustrate how different actors (the Slovenian Development Agency, NGOs, and the Hungarian state) have very similar concepts regarding the development of the area (SzENTGOTTHÁRD 2005). However, these eco-friendly initiatives mostly attract domestic tourism, while crossborder programs are very rare. 
Case studies have shown that when protected natural resources become valuable economic assets in a territory where local farmers are still active, conflicts may easily arise (KONTOLEON et al. 2008). In Europe, conservationists typically work according to the general principles of conservation (TURNER 2005:11-16). Local communities rarely have an opportunity to voice their opinions through the legal system or with respect to local development (LARSÉN 2008). There is also a marked lack of communication between conservationists and local farmers, which means that certain messages do not come across. This lack of communication can partly be explained by the low level of trust among marginal communities towards the outside world, and the bad experiences of local inhabitants with respect to state institutions and outsiders.

In order to obtain a comprehensive picture of an area, it is important to bring together natural scientists and anthropologists. One of the main questions explored in the present issue is how to transcend epistemological and methodological boundaries between the humanities, the social sciences, and the natural sciences. As the editor of the volume, I believe that the articles featured here are good illustrations of how complementary research methods and perspectives are able to provide a clear and accurate picture of the complex social and natural processes taking place in the area.

\section{TRANSCENDING BOUNDARIES}

In order to provide relevant comparative data, research work was carried out with the same intensity in Hungary and Slovenia, and among Slovenian and Hungarian communities on both sides of the border. In the northwestern part of the Hungarian-Slovenian border area, Slovenians form minority communities in Hungary, whereas in the southeastern part of the border area there are Hungarian village communities in Slovenia. As a consequence, it would be both difficult and pointless to undertake independent research work in the border region. The work done by the Hungarian and Slovenian teams was thus not only interdependent, but also essentially overlapping. This methodology of collaborative research work was a necessity in this project, since neither the Hungarian nor the Slovenian research team comprised the full range of research expertise.

At the same time, the intention was to propose a new epistemological framework for understanding local networks of human and non-human agents. After nearly a decade of research work, it is clear that local farmers hold a different opinion regarding the current environmental changes caused by human development. Whereas previously they were able to estimate and foresee changes in weather conditions and flora and fauna and could assess the impact of their economic activities on their environment, the intimate relationship between local farmers and the environment has now been broken and the environment is reacting in unpredictable ways to local farming practices.

Contemporary community-based studies focusing on changing landscapes and agricultural activities in the light of $21^{\text {st }}$-century environmental and economic changes typically use terms (borrowed from ecological science) such as resilience, adaptation, and vulnerability. This approach attributes to communities the ability and capacity to face a variety of environmental and economic challenges (OLIVER-SMITH 2016). Local communities and individuals are seen here as "agents": they are not merely responding to environmental and economic problems or undergoing changes but are playing an 


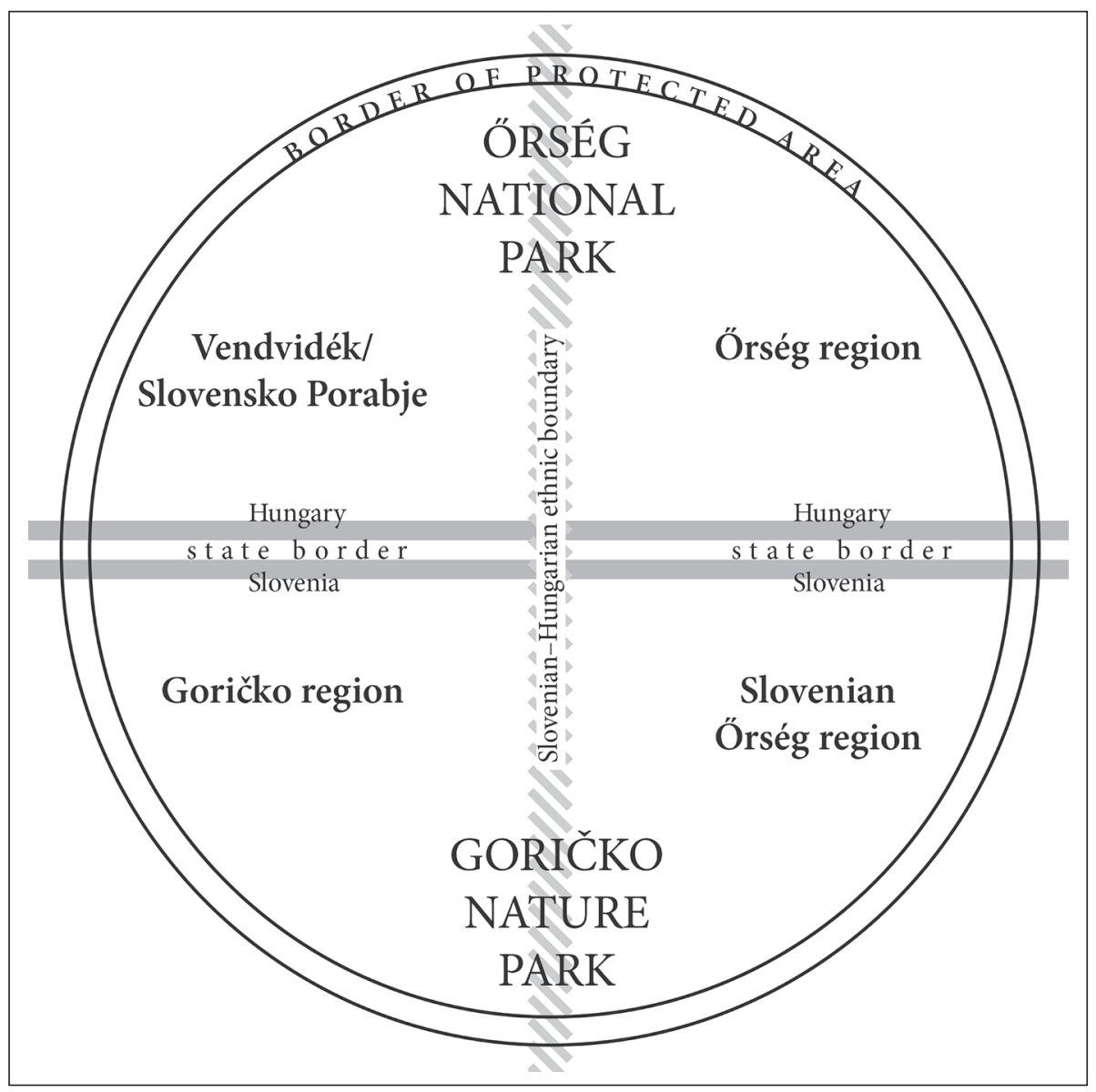

Figure 1. The interplay of state, legislative and ethnic borders in the region

active role in local processes. The present series of articles aims to give these local communities a voice and to regard them as agents in the processes that are taking place.

The articles in the present issue combine different research methods and interests. The first two articles, by Katalin Munda Hirnök and Ingrid Slavec Gradišnik, present an interesting interplay between the region's historical past (The Slovenian-Hungarian Border: A Historical Outline) and the imaging, or "presencing," of that past as the memory of a lived-in world ("Eyes Have No Borders." Presencing the Slovenian-Hungarian Border in Goricko and the Rába Valley). The two articles shed light on the enormous potential of the historical approach in terms of examining present attitudes and emotions in an area where borders have been changed continuously. Ágota Ispán then presents an instructive and meticulous case study on the fate of a housing modernization program in the region. Her article points to how the built environment may be called into play when seeking to understand developments in an area known for its pristine environment.

Two articles then examine recent changes that have taken place in the region. Tatiana Bajuk Senčar focuses on the concept and process of debordering, and on how 
the implementation of EU principles stimulates cross-border activities on both sides of the border. The author concludes that research should focus to a greater extent on how actors in these regions embed their EU project experiences into their perception of borders. Marjeta Pisk presents an individual case study on the challenges of cross-border cooperation between nature parks in the Austrian-Hungarian-Slovenian tri-border area. It becomes clear from her work that EU debordering strategies are not always effective in the realm of nature conservation. Through a study of local pumpkin seed oil pressing practices, László Mód highlights how the opportunities offered by the protected status and peripheral position of the area contribute to the successful marketing of an agricultural product. He demonstrates how a formerly marginal element of the local diet has emerged as a brand for the region as a whole.

Dániel Babai and Viktor Ulicsni present two parallel articles on plant and animal knowledge among local experts. They demonstrate convincingly that the incongruity between local environmental perception and environmentalists' perspectives on nature may lead to discrepancies when assessing the role and place of institutionalized nature protection. A similar question is explored in Miha Kozorog's article, which highlights the parallel existence of incompatible ideas about wildlife in the area. Csaba Mészáros's article, which closes the volume, argues that incompatible ideas arise not only in the context of wildlife, flora, and fauna, but also in the evaluation of the work of village authorities. His study on the records of annual public hearings in the area demonstrates how local voices are scarcely to be heard even in the forums of local political life.

\section{REFERENCES CITED}

BíRó, Friderika

1975 Az Örség ház- és lakáskultúrája a 18. sz. végétöl napjainkig [Home and Interior Design in the Örség Region from the End of the $18^{\text {th }}$ Century to the Present Day]. Szombathely: Savaria Múzeum.

Degler, Carl N.

1989 Culture versus Biology in the Thought of Franz Boas and Alfred L. Kroeber. New York - Oxford - Munich: Berg. (German Historical Institute, Annual Lecture Series No. 2.)

Descola, Philippe

2013 Beyond Nature and Culture. Chicago: University of Chicago Press.

DöмÖтÖR, Sándor

1960 Örség. Budapest: Gondolat.

FEHÉRVÖLGYI, Beáta

2010 Határtalan lehetöségek a határ mentén [Limitless Opportuities along the State Border]. Doctoral Thesis. Veszprém: Pannon Egyetem, Gazdálkodásés Szervezéstudomány Doktori Iskola. http://konyvtar.uni-pannon.hu/ doktori/2010/Fehervolgyi_Beata_dissertation.pdf (acessed October 04, 2020) 
GRÁFIK, Imre

1995 Adatok a füstösház, illetve a füstöskonyhás ház nyugat-magyarországi elterjedéséhez [Data on the Use of Smokehouses and Smoke Kitchens in Western Hungary]. In Cseri, Miklós - Bíró, Friderika - NaGY, Zoltán (eds.) Nyugat-Dunántúl népi építészete, 51-80. Szentendre - Szombathely: Szabadtéri Néprajzi Múzeum - Savaria Múzeum.

KERNY, Terézia

2005 A veleméri Szent László-freskó XIX. századi feltámadás [The 19 ${ }^{\text {th }}$-Century Resurrection of the Saint László Frescoes in Velemér]. Ars Hungarica 33(12):331-362.

Kogutowitz, Károly

1930 Dunántúl és Kisalföld írásban és képekben I-II [Transdanubia and the Little Hungarian Plain in Text and Images, I-II]. Szeged: Magyar Királyi Ferenc József Tudományegyetem Földrajzi Intézete.

Kontoleon, Andreas - Pascual, Unai - Smale, Melinda (eds.)

2008 Agrobiodiversity Conservation and Economic Development. London: Routledge.

LARSÉn, Karin

2008 Farmers' Participation in Agrienvironmental Programs and Impact on Farm Performance. An Empirical Analysis Applied to Swedish Agriculture. In Kontoleon, Andreas - Pascual, Unai - Smale, Melinda (eds.) Agrobiodiversity Conservation and Economic Development, 392-405. London: Routledge.

Moнos, Mária

2008 A Rábától a Muráig. A magyar-szlovén határtérség történeti-földrajzi vizsgálata [From the Rába to the Mura. A Historical-Geographical Survey of the Hungarian-Slovenian Border Area]. Szombathely: Bibliotheca Slavica Savariensis X.

NAGY, Zoltán

1999 Egy történeti kistáj, az Örség néprajzi határainak vizsgálata [A Historical Microregion: An Examination of the Ethnographical Borders of the Örség Region]. Savaria. Vas Megyei Múzeumok Értesítője 22(4):145-180.

NEMESNÉPI ZAKÁL, György

2002 (1818) Eörséghnek Leirása ugymint: Annak Természete, Története, Lakosai ezeknek szokásai, nyelvszokása a'mellyeket öszve szedegett Nemes-Népi Zakál György: 1818-dik Esztendőben [A Description of the Örség Region: Its Nature and History, the Customs of Its Inhabitants, and Their Vernacular, as Collected by György Nemes-Népi Zakál: In the Year 1818]. Szombathely.

Oliver-Smith, Anthony

2016 Disaster risk reduction and applied anthropology. Annals of Anthropological Practice 40(1):73-85.

PÁVEL, Ágoston

1936 Örségi képek [Images of the Örség]. Vasi Szemle 1936(5-6):318-338.

Prinz, Gyula

1922 Magyarország településformái [Forms of Settlement in Hungary]. Budapest: Hornyánszky Viktor Magyar Királyi Udvari Könyvnyomdája. 
SZENTGOTTHÁRD VÁROS

2005 Szentgotthárd város idegenforgalmi fejlesztési koncepciója és stratégiai programja [Tourism Development Concept and Strategic Plans of Szentgotthárd]. http:// nagyrakos.hu/szentgotthard/download. ashx?type $=$ file $\& i d=381$ (accessed October 10, 2020)

TURAI, Tünde (ed.)

2015 Hármas határok néprajzi értelmezésben / An Ethnographic Interpretation of Tri-Border Areas. Budapest: MTA BTK Néprajztudományi Intézet.

TuraI, Tünde - MÉszÁros, Csaba (eds.)

2015 Hármas határok néprajzi nézetben. An Ethnographic Perspective on TriBorder Areas. Budapest: MTA BTK Néprajztudományi Intézet.

TURNER, Nancy

2005 The Earth's Blanket. Vancouver - Toronto: Douglas \& McIntyre.

VAKARCS, Károly

1949 Örség néprajza [The Ethnography of the Örség Region]. Kézirat. Szombathely. VöRös, Antal

1970 Az őrségi gazdálkodás az úrbérezéstől a XX. század elejéig [Agriculture in the Örség Region from Feudal Tenure to the Beginning of the $20^{\text {th }}$ Century]. Vas megye múltjából III. Levéltári kézikönyv, 217-235.

Open Access. This is an open-access article distributed under the terms of the Creative Commons Attribution 4.0 International License (https://creativecommons.org/licenses/by/4.0), which permits unrestricted use, distribution, and reproduction in any medium, provided the original author and source are credited, a link to the CC License is provided, and changes - if any - are indicated. (SID_1) 